\title{
Sexless Marriage in Japan as Women's Political Resistance
}

\author{
Rika Tsuji ${ }^{1 *}$
}

Published: September 27, 2018

\begin{abstract}
A recent survey by the Japan Family Planning Association (JFPA) shows that nearly half of married couples in Japan are in sexless marriages. Japanese society is paying attention to sexless marriage because it is considered to be related to prolonged working hours and the current low total fertility rate. However, this interpretation of the phenomenon ignores the social conditions of sexuality and marriage relations in Japan, in which the sexuality of heterosexual married women is objectified for the needs of men in a patriarchalandrocentric society. I will use Judith Butler's theory on gender performativity to analyse the gendered aspect of sexless marriage, and argue that sexless marriage should be viewed as a form of women's political action against the present power system. This discussion corresponds to other related phenomena such as postponing marriage, choosing men who do not demand women to be housewives, not bearing children, and staying single. These women's choices can and should be understood as political actions that resist constructed social norms and expand women's modes of agency within the norms of Japanese femininity.
\end{abstract}

Keywords: sexless marriage, gender performativity, political action, Japan

\section{INTRODUCTION}

The Japan Family Planning Association (JFPA) recently published a survey that reported that almost half of married couples in Japan are in sexless marriages (Kitamura, 2015). Not long after, Tomomi Yamaguchi (2016) provided critical insight into a similar survey about Japanese sexuality by questioning the heteronormative assumptions, accuracy, and popular media articulations of the survey. Yamaguchi's article also questions the reception of the 'sexless' phenomenon by Japanese society, which is largely focusing on this phenomenon because it is considered to be related to Japan's low total fertility rate. For example, Japan's total fertility rate was 1.42 in 2014 (this number represents the average number of children that a woman produces in her lifetime). However, Yamaguchi's article focuses on the increasing pressure faced by single people to find heterosexual partners; in other words, it is an analysis of 'sexless singles.' While her questioning of the heteronormative bias in the survey is an important contribution, this paper is an attempt to initiate a critical sociohistorical analysis of the wider implications of the 'sexless marriage' phenomenon.

Increasing weight has been placed on working conditions as one of the causes of sexless marriage, since more than $30 \%$ of men in the JFPA survey gave the reason that they were 'too tired to have sex because of work' (Hosokawa, 2017). Thus, sexless marriage is increasingly thought to be caused by lack of time and energy, especially for men. However, this interpretation of the phenomenon does not consider the struggles related to women's marital sexuality in Japan, even though the most common reason given for sexless marriages by married women was mendökusai, hassle. Japanese speakers use the word mendökusai when they feel reluctant to do things that they are obligated to do.

What makes women feel like having sex is a hassle in their marriages? Judith Butler's theory on gender performativity is key in considering this question. Butler (2009) states that gender is performative, explaining that:

gender is prompted by obligatory norms to be one gender or the other (usually within a strictly binary frame), and the reproduction of gender is thus always a negotiation with power (...). (p. i)

That is, the binary of gender between men and women is a social construction produced by norms that reflect dominant discourse, which constantly regulates what one can be as a gendered subject. Thus, Butler (1993) indicates that this process of performativity must be understood in light of the historicity of discourse, instead of 
being seen as a single act. Yet importantly, her account of performativity makes us aware that resistance against norms matters. Gender norms are not unchangeable, as subjects are not unchangeable. Butler's account of gender performativity shows that experiences where gender is involved are inseparable from social and cultural discourse. This suggests that to understand the phenomenon of sexless marriage in Japan requires a historical analysis of discourse on gender and sexuality, because, as a gendered issue, it is part of a reiterative process of normativity which by necessity happens through long spans of time and political interaction rather than singular data points. Through this analysis, I will argue that contemporary sexless marriage can be, for a woman, a political act in which she resists the constructed social norms that signify women only in relation to reproduction, motherhood, and androcentric values. A married woman's choice not to have sex is not merely a random action, but rather it can, and should be, understood as resistance against dominant sexual discourses in Japan, which limit her modes of agency in the presence of gender inequity. The argument of women's abstinence as political resistance can be possible only if we understand that gender is performative, and performativity is a reiterative process that normalises gendered subjects; Butler's philosophical framework of gender performativity makes it possible to reveal the conceptual barrier that prevents us from seeing that saying 'no' to marital sex, for a woman, is a political action rather than simply a private matter. ${ }^{1}$

I begin by examining the social conditions of sexuality in two different periods of Japanese history. The first period is that of the regime of Japanese imperialism (the mid-1870s to 1945), where sexual and gender norms were constructed and reinforced in the process of modernising Japan into a nation-state. The other is during the postwar period, when capitalistic patriarchal society needed women to provide free labour as housewives to maintain economic growth, and when, at the same time, the sex industry became a significant part of business culture in Japan. ${ }^{2}$ This historical analysis reveals a certain level of continuity in the social conditions of sexuality in the capitalist-patriarchal-androcentric society of Japan. To say that sexless marriage is a form of women's political resistance also requires reconsideration of the current conception of political actions in the Japanese context. In other words, we need to examine what has been considered as legitimately 'political' in Japanese history. This kind of examination will illuminate a binary lens through which women's lived experiences have been thought to be domestic matters, and thus apolitical. In this light, we can politicise related phenomena surrounding women's sexuality, such as the increasing number of women postponing marriage, bearing no children, and staying single. These women's choices can and should be understood as political actions that resist constructed social norms and expand women's modes of agency within the norms of Japanese femininity.

\section{SEXUALITY IN JAPAN FROM THE MEIJI PERIOD (1868)}

一盗二婢三妾四妓五妻—ittō nihi sansyō shigi gosai

(1 $1^{\text {st }}$ another man's wife, $2^{\text {nd }}$ a maid, $3^{\text {td }}$ a mistress, $4^{\text {th }}$ a prostitute, $5^{\text {th }}$ own wife.)

This old Japanese maxim is a ranking of types of women based on men's sexual fantasies. The most sexually attractive woman for a man is another man's wife, and the least attractive one is his own wife. Considering the maxim, Tamaki Horie (2005) says that a wife can be a very attractive figure for men other than her own husband (pp. 21-22). The old maxim aptly describes the male-dominated sexual discourse during the regime of Japanese imperialism. Husbands having extramarital sex were not a particular problem, especially when the sex was with mistresses or prostitutes (Suzuki, 2013: 330). On the other hand, wives engaging in extramarital sex was not acceptable, as evidenced by kantsüzai, the law relating to adultery. This law applied to those people who had affairs, specifically to married women and their sexual partners, and allowed husbands to file for divorce and for compensation from their partners. The discourse about adultery, therefore, was centred around the notion that a wife's body is her husband's property (Hayashi, 2017; Suzuki, 2013; Ueno, 2003). The moral and legal code of chastity did not equally apply both to men and women, but more heavily criminalised married women.

Why were some women, such as prostitutes, allowed to be sexual objects for men if women were subject to the code of chastity? In other words, with what conceptual lens did men distinguish non-married women as acceptable sexual objects, and married women as non-sexual beings? This question can lead us closer to an understanding of how gender has been constructed through performativity, corresponding to male-dominated sexual discourse. Hiroshi Yamane's work on sexuality in the Meiji period (1868-1912) shows that the concept 'love' was introduced from the West to Japan during the early modernisation period, and the concept was somewhat

\footnotetext{
${ }^{1}$ The general claim that private matters are political is not original. This critical analysis of the dichotomy between the public and the private has been contributed by many feminist scholars, especially in Anglo-American tradition. For further information, see Joan B. Landes, ed., (1998), Feminism, the Public and the Private. (New York: Oxford University Press).

${ }^{2}$ It should be noted that I can only offer a brief sketch of the social conditions of married female heterosexuality due to the length of periods that I cover and the limited space in this paper, and I mainly analyse the history of heterosexual normativity in Japan, as this paper aims to discuss sexless marriage: marriage is still thought to happen between one heterosexual man and woman. Yet importantly, this is not to deny the existence and history of queer sexuality in Japan, of which further analysis is needed.
} 
difficult to describe in pre-existing Japanese vocabulary; thus, a new word, ren'ai, was coined for love (Yamane, 2008: 315-317). Yamane states that when this new concept 'love' arrived, Japanese intellectuals argued that the word 'love' was different from pre-existing concepts related to affection since such concepts included impurity, i.e., sexual desire. According to Yamane's historical analysis of men's sexuality in the Edo period, men had sought prostitutes for novelty and their wives for stability; the novelty implied sexual fantasies and the stability indicated procreation. In other words, men considered that the main purpose of marriage was procreation that did not necessitate 'love,' whereas they needed prostitutes to excite their sexual desire. Thus, the introduced concept 'love' was thought to be unsuitable for describing a marital relation between a husband and a wife at that time (Yamane, 2008: 315-319).

Arguably, this history of men's sexual preferences suggests that there were two different types of sexual activities for men: reproductive sex and sex for pleasure. That is, a husband considered his wife to be primarily for reproductive sex, whereas he considered other women to be potential sexual objects who could satisfy his need to enjoy non-reproductive sex. ${ }^{3}$ In considering the adultery law, the dichotomy between non-reproductive sex and reproductive sex was created on the basis of male-dominated sexual discourse which invited discrimination against those women who transgressed the boundary.

Yōko Hayashi's account of the newly modernised licensed prostitution system might explain how and why the society and the government attempted to maintain the dichotomy between non-reproductive sex and reproductive sex. The licensed prostitution system was introduced during the late $19^{\text {th }}$ century and continued through the end of WWII, in which licensed prostitutes were forced to undergo inspections for syphilis (kenbar) (Hayashi 2017). First, Hayashi (2017) states that the Japanese imperial government created the licensed prostitution system due to serious concerns about the spread of sexual diseases among men, i.e., men's sexual hygiene, because many men became not only carriers of sexual diseases but also transmitters among both prostitutes and their wives, who were responsible for producing healthy offspring. Arguably, the government legalised prostitution specifically for nonreproductive sex, by enforcing syphilis inspections of licensed prostitutes, in order to protect reproductive sex. Second, Hayashi says that the licensed prostitution system was inseparable from the gender norms of men's sexuality at that time. There was an assumption that men naturally possess 'unlimited sexual desire,' as opposed to the assumption that women naturally do not possess this same desire; thus, men need prostitutes like they need toilets for excretion (Hayashi, 2017: 447). In short, society and the government justified sacrificing some women to be prostitutes for the need of men's sexual desire and forced licensed prostitutes to undergo the syphilis inspection regularly in order to keep men's bodies safe. That is, prostitutes' bodies were used for the common good (Hayashi, 2017: 56). The dichotomy between non-reproductive sex and reproductive sex was maintained through the licensed prostitution system for the sake of male-dominated sexual discourse.

A well-known ideology of women during the Japanese imperial regime was ryösai kenbo (good wives, wise mothers), which reinforced gender norms of femininity by encouraging women to be educated to be good wives and mothers for family and society. This was an idealised role of women in patriarchal society; patriarchal society idealised women to become domestic (Mackie, 1995: 5-6). Moreover, women were barred from participating in politics by a law passed in 1890 . These social conditions made it difficult for women to be political as they were ought to talk only about domestic matters (Hayashi, 2017: 106-118). Notably, some women, including abolitionists of the licensed prostitution system, supported colonialism, which ironically justified the violence and exploitation against some women and girls of their own country, as well as other countries living under Japanese imperialism (Hayashi, 2017). This means that women could not socially form a coalition to advocate for human rights for all women. Thus, Hayashi (2017) indicates that men were the main activists in the abolition movement since the discourse was oriented around a new 'manhood' as the symbol of civilisation; male abolitionists claimed that civilised men were opposed to the savage men who could not control their own sexual desire (pp. 447-458). Having said that, male abolitionists did not simply abolish all kinds of sexual desire to become civilised men. They believed that sexual desire can be natural and sacred for reproduction purposes. Sexual activities for reproduction, therefore, should be derived from appropriate sexual desire, which should only happen within marital relations. Hayashi mentions that those who wanted to promote civilisation considered the modern structure of family as an idealised institution where sexual desire and reproduction can be combined (Hayashi, 2017: 455-458; Mackie, 1995: 5-6).

Discourse by male abolitionists did not necessarily consider the subjectivity of women but rather reinforced men's subjectivity by developing a new conception of manhood. Analysis of this political environment suggests that men dominated the movement, yet women's political actions did not necessarily advocate for the rights of all women. This could be attributed to the fact that these female actions were restricted by institutional gender

\footnotetext{
${ }^{3}$ This distinction does not mean that all infants were born from intentional reproductive sex; there was always a possibility of unintentional pregnancy resulting from non-reproductive sex. For example, a graphic satire published in the late $19^{\text {th }}$ century illustrates a pregnant woman who does not know the man who made her pregnant. Yōko Hayashi says that such satires were not unusual and the intention was to exhibit contempt for women who had been fooled by men. The stigma of unwanted pregnancy had to be borne by any women who became pregnant if the pregnancy was attributed to non-reproductive sex. See Hayashi, 2017.
}

(C) 2018 by Author/s 
segregation and by social and cultural discourse, such as seen in the ideology ryösai kenbo, concerning gender and sexuality in patriarchal androcentric society.

As Butler (1993) explains, gender is not constructed within a day but through a repetitive process over a long period, as it is performative. Japanese discourse materialises a specific model of heterosexual femininity that produces feminine subjects whose agency is constrained in relation to heteronormative masculine desire. ${ }^{4}$ This makes it difficult for women to advocate for their rights, because the concept of heterosexual femininity does not encourage women to care for themselves but always for somebody else, such as the nation, the emperor, fathers, husbands, and children.

\section{SEXUALITY IN THE POST-WAR PERIOD}

内助の功—naijyo no kò

(the success due to wife's help)

This Japanese maxim describes a situation in which a husband successfully achieves something, thanks to his wife's help. Nai means 'inside,' and jyo means 'help,' so the literal translation is 'inside help.' Husbands sometimes describe their wives as kanai, which literally means 'inside the house.' The term kanai implies that a wife is someone who stays inside the house, and this maxim 'naijjo no ko suggests that a wife's help is not something shared with her husband in public, shoulder to shoulder, but rather arises from inside the house. This means that she stays invisible, unless her husband states this maxim to show his gratitude in public. The implication of this scenario is as if husbands own their wives for the needs of their own success.

There was a social shift for married women during the mid-1950s to 60s when Japan experienced rapid economic growth. During this period, Ayako Kano (2016) says that developing industries dragged married women away from the house, and yet importantly, married women also sought jobs to meet a better standard of living. This became possible because of a change in the social and material structure (pp. 117-120). For example, Yasuko Tama (2009) states that the family planning movement initiated by the Japanese government and supported by corporations during post-war economic growth sought population control. Married women were encouraged to have fewer children to form small-sized families, which benefited wives, husbands' corporations, and the Japanese economy. As a result of smaller families, wives found it possible to spend more time on child raising, selfimprovement, financial planning, and working part-time. As for corporations, they could reduce the amount of welfare for the employees' families and make married-male employees devote their whole lives to their work (pp. 304-317). At the same time, technological development, such as the advent of rice cookers and inexpensive readymade food, changed material realities for housewives, which reduced their labour hours inside the house (Kano, 2016: 118-119). A small nuclear house became an ideal model for the Japanese post-war economy, in which housewives played a very important role as an economic foundation.

Yet, married women were still not socially and culturally expected to be breadwinners; they were considered to be housewives regardless of whether they had an outside occupation (Kano, 2016: 117-120). In the 1970s, there was a societal debate concerning the relation between mother and child, which was about the so-called three-yearold-myth. According to Nobuko Uchida (2010), this myth argues that:

For the sake of healthy psychological childhood development, children should spend every single day from morning to afternoon with their mother until they become three years old. (pp. 76-77)

This myth coincided with women's entrance into the labour force (Uchida, 2010). Although there is no scientific evidence to suggest that the amount of time spent with mothers is related to psychological defects in their children, this myth remains in Japanese society as biological 'truth.' This mind-set prevents employed mothers from utilising nursery schools or nannies. It also assumes that mothers who are not with their children 365 days a year are not good mothers (Uchida, 2010: 77-83). Kano (2016) indicates that later Japanese society perceives this 1970s' family structure (the full-time housewife and the male breadwinner) as the 'traditional Japanese family,' and conservatives in particular use this quasi-tradition to reject policies for gender equality (pp. 159, 168). In short, women who have children are deemed to be solely responsible for domestic work and child raising regardless of whether they had occupations or if they wanted to work outside the home.

What, then, were the expected tasks of husbands as full-time employees? Anne Allison's anthropological work (1994) on mi₹u shöbai, the nightlife business in Japan, reveals the tight relationship between corporations and nightlife entertainments. She shows that business outings (settai) paid for by corporations became common practices, especially among large corporations, in the period of post-war economic growth. Business outings with workers or clients were thought to be a very important part of successful business since settings away from work

\footnotetext{
4 This does not deny the diversity of femininities or masculinities already existing within Japan, but rather suggests that within heteronormative discourse, women are reiteratively constructed as providers of sexual service for masculine subjects.
} 
can fortify workers', especially male workers', relations and bonding. Allison (1994) points out that from 1954 to 1982, corporations were legally allowed to treat most of their corporate entertainment expenses as tax-deductible (p. 9). In short, the government legitimised this business culture as an accepted norm. Allison's own field research in a high-class hostess club in Tokyo shows how white-collar male workers strengthen their homosocial bonding in relation to hostesses' performances. First, a hostess club is legally considered as a settai restaurant, in which male customers chat and drink with female hostesses who usually offer great hospitality to the customers. Allison describes hostess clubs more in details as follows:

The hostess must be, or must act like, a woman; the hostess must treat the customer as a superior and tend to his various desires; the service, while alluding to sex, cannot proceed to genital penetration or oral sex; and the service is conducted primarily at the level of conversation. In short, what characterizes the hostess and differentiates her services form that offered by others in the mizu shyobai is that her medium of service is primarily talk. The job of the hostess, as both speaker and listener, is to make customers feel special, at ease, and indulged. Or, as one Japanese man told me, the role of the hostess is to make a man "feel like a man." (pp. 7-8)

That is, hostess clubs allow male customers to perform an ideal manhood through subjecting ultra-feminised women to the male gaze. Men become 'masters' not through their physical domination of hostesses' bodies, such as direct sexual activity, but based upon the promise that any speech, including dirty talk such as 'your boobs are my type,' will be not only listened to, but also accepted and praised as flattery (Allison, 1994: 22, 46-49). Allison refers specifically to Hegel's theory of the master-slave narrative: men can maintain their identity as masters only when hostesses as slaves serve up their flesh as sustenance for masters; thus, masters cannot exist without slaves (pp. 164-167).

Allison describes this flattering talk as foreplay, differentiating it from other ways of having the sexual excitement and sexual desires in the sex industry. Indeed, there are plenty of other places for men to achieve ejaculation in the sex industry, but a hostess club is a place where they can perform their heterosexual masculinity together (pp. 20-21). Hostess clubs are important places for men to strengthen their common bonds of mastery by distancing themselves from women; the objectification of the female workers in the form of male homosocial bonding becomes an important means to reaffirm those male customers' masculinity.

According to Allison's interviews with Japanese married women, some women considered that their husbands' absence from their home due to after-work entertainment is an inevitable part of their job. It is a common understanding that white-collar husbands work hard into the late night and are absent from their homes, and mothers become used to being in families where their married partners play little active role in the home (pp. 102107). These social conditions illustrate that almost anywhere men do not have to perceive themselves as fathers and husbands is a place for men's homosocial bonding, whereas almost anywhere women are signified as wives or mothers can be their spaces for homosocial bonding, such as homes, their children's schools, and part-time employment sites. While homosocial bonding itself is not necessarily wrong, since it helps to form communities, the issue is the ways in which homosocial bonding tends to reinforce gender-based segregation, which, moreover, tends to signify men's positions over women's within the capitalistic-patriarchal-androcentric society. Women cannot gain legitimacy in male-dominated business spheres, unless women perform ultra-feminised, normative gender roles. In other words, if society considers the practices of male homosocial bonding as a necessary part of successful business, women will remain marginalised.

That said, I am not attempting to deny the legitimacy of sex workers or those who work for hostess clubs, nor to victimise those who perform ultra-feminised gender roles for their clients. For some sex workers, their work may carry the possibility of exemption from the marital obligation to perform reproductive sex. Nevertheless, this also does not mean that all workers live in the non-reproductive realm. Some people, such as single mother sex workers, live in both worlds, which should not be overlooked. While we should acknowledge the diversity and fluidity of different ways that women in Japan live, the issue that we need to address here is that there is a strong gender-based segregation in socio-political contexts which allows men to continually exploit women. Accordingly, single female full-time workers are marginalised in this dichotomy and they can be delegitimised as workers if society sees them as potential housewives or mothers. As Allison's work shows, men prey on women to be successful in business as a part of heterosexual normativity. This normativity is justified by the sustenance of the domestic sphere where the roles of husbands or fathers are not significant other than in their obligation as breadwinners. 


\section{POLITICAL RESITANCE OF WOMEN IN JAPAN}

公私混合 $-k o \bar{s} h i k$ i kongō

(the mix of public and private matters)

Köshi kongo is a Japanese maxim that implies the negative connotation of mixing public and private matters. Japanese speakers usually use this maxim to criticise someone for bringing personal matters to his or her public sphere, such as the workplace. For instance, if a female worker takes a day off due to family matters such as her child's sickness, she could be criticised for not being professional since she cannot keep her private matters away from her work. The above maxim confirms that there is a dichotomy between the public and the private, and that normatively, these spheres should always be separate and should not be integrated, for the sake of the public good. This implies that there is a clear-cut line separating the public and private spheres (Allison, 1994: 80).

Japanese business practices, such as business settai, show that 'work' as public is vaguely defined, because hours spent outside of employment are considered to be 'work' if the hours are related to so-called business entertainment. The dichotomy of public and private in this context is set on the notion that things related to paid work are public, and the rest is private. In other words, anything related to unpaid matters, such as family, is private or personal, which, according to this maxim, should not interfere with public spheres. Therefore, this boundary can potentially marginalise anybody who is subject to both spheres, such as married women who have full-time jobs. Single female workers can also be marginalised due to this dichotomy since society perceives them as potential mothers. As Kano (2016) states:

Indeed, in much of the policy discourse on women in modern Japan, womanhood has been equated with motherhood, and all women have been understood to be potential mothers. Modern gender policy has been driven by the assumption that all women will at one point become mothers - and that almost all of them will do so within the context of a married family life. (p. 106)

That is, regardless of women's social status or their sexual orientation, society sees them as potential caretakers of private matters. In Japan, women are born to be mothers. The presumption of women as mothers conditions women to fulfil their reproductive role in the private sphere. This suggests that the political dichotomy of the public and the private spheres mutually reinforces the sexual dichotomy between non-reproductive sex and reproductive sex. The presupposition that all women are potential providers of reproductive sex is a key factor in the segregation of women from public spheres; this assumption keeps women away from the workplace and marginalises women in a money-worshiping society.

However, it is important to note that this reinforcement of the sexual dichotomy does not only marginalise women, and my analysis may not adequately articulate all aspects of marginalisation. For example, as Takashi Kazama (2003) points out, homosexual couples are illegitimated both in public spheres and private spheres, due to heterosexual social norms. Kazama's work (2003) draws a distinction between the public and the private based on heterosexuality. The private is the sphere wherein men and women have intercourse, and the public is where such sexuality has to be omitted, i.e. it is asexual. Following this distinction, a homosexual couple could not fit in either the private nor the public since, first, they are not one man and one woman, and secondly their sexual identities cannot be revealed due to the asexuality of the public (Kazama, 2003: 34).

Nevertheless, marriage made heterosexual men's desire sacred, because it was seen as a legitimate means to achieve reproduction. Thus, reproductive sex became the symbol of modern monogamous families in Japan. In turn, the social institution of marriage has helped to maintain the dichotomy between non-reproductive sex and reproductive sex. In 1987, the Japanese Supreme Court case judgement in a divorce case stated the definition of marriage as follows:

To our way of thinking, the nature of marriage is to live devotedly with a spouse in permanent mental and bodily unification of the sexes; thus, when one member of the couple or both decisively lose the will to pursue this unification, and when there is no potential recovery from the loss, it becomes unnatural for this marriage to remain in the family registry since it lacks the actuality of its fundamental function in society. ${ }^{5}$

The juridical definition of marriage, in short, is the unification of mind and body between the two sexes. According to the definition, to maintain a marriage, married couples are obligated to pursue this unification permanently. In considering the history of marital sexuality in Japan, the permanent unification of bodies implies

\footnotetext{
${ }^{5}$ See Rikon [Divorce], Supreme Court of Japan, 民集 41 巻 6 号 1423 頁 [vol. 41, no.6, p.1423], (2 September 1987). Available at http:/ / www.courts.go.jp/app/hanrei_jp/detail2?id=55213 (Accessed 21 January 2018). This translation is mine and emphasis is added.
} 
reproductive sex rather than non-reproductive sex since reproductive sex is perceived as a privilege for married couples. In this regard, reproductive sex becomes an obligation, and non-reproductive sex is a choice. ${ }^{6}$

Considering this history, how should we understand the current phenomenon of sexless marriage in Japan? According to the survey published by JFPA, nearly half of married couples are in sexless marriages (Kitamura, 2015: 5-6). In considering Japanese tradition, sexual activity within marriage is a private matter that should not be discussed in the public sphere. However, Japanese society has politicised this private matter as they consider it to be related to prolonged working hours and the current low total fertility rate (see Gotō, 2015; Hosokawa, 2017; McCurry, 2017). In such political discourse, there is no implication that sexless marriage is a form of women's political action against male-dominated sexual discourse that always already sees women to be married for reproductive sex, which historically has enabled men and women to see women as apolitical.

Arguably, the prolonging of men's work hours, and therefore resulting in a lack of men's time and energy is not a major reason for sexless marriages even though it could still influence sex drive. As noted, the working culture established during the post-war period has diminished the role of husbands within the home since husbands are culturally exempt from spending any time and energy in the domicile anyway. According to the data published by the Cabinet Office, average hours of labour per person for a year in 1970 was 2,214.5, whereas that in 2008 was 1,835.0.7 This shows that the average of work hours significantly declined from the 1970s to the 2000s; if sexless marriage is related to the length of men's working hours, then the issue should have been improving for 30 years. Likewise, in data from 2016, the Cabinet Office shows that husbands with children under 6 spent more time 83 minutes) per day for domestic chores, including taking care of their own children, than they did in 2011 (67 minutes). ${ }^{8}$ Thus, the lack of men's time and energy due to work as a major factor of sexless marriage is not a strong inference. Interestingly, absence of husbands from the home of course can affect the frequency of sexual activity with their wives; but it does not necessarily affect their frequency of extramarital sex. According to Chineko Araki's survey on the sexuality of middle-aged men and women, the number of those men who have extramarital relations including prostitution increased from 2000 to 2012, whereas that of their marital sex decreased during the same period. Those married men who do not have sex with their wives have 1.7 times more extramarital relations than those married men who have sex at least once a month with their wives. She also denies the loss of libido since more married people, both men and women, reported that they masturbate more often than in 2000 (Araki, 2017: 2-4).

These analyses rather suggest that sexless marriage can be attributed to the current social situations surrounding women. Araki (2017) suggests that more married women became capable of saying 'no' to their sexual life, as they may have more economic power and may consider marital relations and sexual activity insignificant (pp. 2-4). As JFPA's survey shows, the most common reason given by married women who are in sexless marriages is 'mendökusai', hassle (Kitamura, 2015). The word mendökusai does not specify much of the situations that make them feel hassled. However, people say mendökusai when they acknowledge that they need to do things that are not appealing. For example, mothers express mendokusai about laundry since they are aware that laundry is their job at home and yet they are not happy to do it. Thus, those women who feel hassled by sexual activities may perceive having sex to be an obligation of wives to their husbands, an obligation they do not enjoy fulfilling. JFPA's survey published in 2017 shows that the most common male view of having sex with their partners is for sexual pleasure, comfort, and body contact, whereas that of female view of having sex with their partners is for love, procreation, and obligation (Kitamura, 2017: 5). Sexless marriage is not simply a matter of libido nor laziness, but arguably it can and should be considered as a potential form of women's political resistance against Japanese sexual discourse derived from sex segregation norms and policies.

Why should sexless marriage be considered to be political resistance? The long history of sexuality surrounding women in Japan shows that women are locked into the dichotomy between what is public and what is private. If we are not aware of this dichotomy, we might not even realise that our identification of political matters is related to this dichotomy. Thus, our definition of politics does not allow women to politicise their experiences, because those experiences tend to be framed as private matters. In other words, failure to recognise women's actions as potential political actions will continue to result in the marginalisation and neglect of women's' struggles, which have their roots in an oppressive political discourse about sexuality.

Butler's account of gender performativity indicates that repetition of the power of identification is the process by which subjects are formed; thus she states that the exposure of this repetition should be considered 'as a critical resource in the struggle to rearticulate the very terms of symbolic legitimacy and intelligibility' (Butler, 1993: 12).

\footnotetext{
${ }^{6}$ The fact that non-reproductive sex is now seen as a choice also masks the exploitative and problematic situation of the sex industry for the women involved by focusing on the male choice.

${ }^{7}$ For the details of yearly record of work hours, see the website for Cabinet Office, Government of Japan (2009). Nippon Keizai 2009-2010 [Japanese economy 2009-2010]. Available at http://www8.cao.go.jp/shoushi/shoushika/data/ottonokyouryoku.html. (Accessed 21 January 2018)

8 See the Website for Cabinet Office, Government of Japan (n.d.). Otto no kyöryoku [Support of husbands]. Available at: http://www8.cao.go.jp/shoushi/shoushika/data/ottonokyouryoku.html (Accessed 21 January 2018)
} 
That is, resistance against gender norms reveals the operation of performativity, which should be used to push the boundary of who are considered to be subjects through resignification of norms. In Sara Salih's interpretation of Butler, Salih (2004) states about this resignification of norms in political performativity that:

A radical democratic politics works to open up the norms which sustain viable life, making those norms available to communities that have previously been disenfranchised, excluded, subject to violence. ( $\mathrm{p}$. 12)

In other words, democratic resistance can expand the boundaries that define acceptable ways of life; thus, it can include those who are marginalised. This suggests that a subject is not fixed but rather that it fluidly changes.

Viewed in light of Butler's account, Japanese sexless marriages can be seen as one way in which the possibilities for women in Japan might be expanded. The choice to resist having sex is becoming more available to those who feel mendōkusai about sexual activity. This resistance reveals gender performativity in Japan, in which institutional power privileges marriage for the sake of reproductive sex. ${ }^{9}$ Furthermore, as Butler (1993) states, her theory of performativity does not refer to a single act of performance but to the reiterative operation of identification; yet it has the possibility of expansion of norms through radical resignification of what can be included in norms (pp. 2122). Thus, viewing resistance to sexual activity as a political matter helps to solidify the reiterative process through which women's 'private' actions can become political ones. Through this resistance, performativity exposes that which prevents women from living outside of contemporary gender norms. This exposure may raise awareness of the dichotomy between the public and the private in relation to the binary between non-reproductive sex and reproductive sex.

Sexless marriage is not the only phenomenon that allows us to see women's experience as political. The fact that there has been repetitive social pressure on women to marry and to bear children suggests that oppression for women, regardless of their marital status, is significant. As Kumiko Nemoto (2008) argues, increasing numbers of women postponing marriage is another contemporary social phenomenon wherein women show their struggle against gender inequity in Japanese society. Nemoto's study indicates that postponing marriage is not a rare phenomenon, especially among those women who have high levels of education and full-time jobs, i.e. privileged women. Women's struggles are not all the same, but there are certain similarities in that those women who postpone their marriage consider that marriage reduces their modes of autonomy and can prevent them pursuing their careers (pp. 226-228). They distance themselves from marriage to sexist men, who tend to see career-track women as unsuitable wives since they are not feminine enough (pp. 228-232). These women also avoid marriage with men who hold lower income and education status than them, since some of these women still consider marriage to be a marker of socioeconomic status (p. 233). Nemoto (2008) concludes her study as follows:

(...)Women want gender equality, which none of their institutions are set up to provide. Thus, they are forced to fashion individual solutions to structural problems. (...) With meager public outlets for their grievances regarding gender inequality and their demands for social change, more women (and possibly men) might resort to strategies such as delaying or completely avoiding marriage and childbearing to cope with their socially suppressed frustration and resentment. (pp. 234-235)

That is, these women may choose to postpone or reject institutional marriage as an expression of opposition to gender inequality in Japanese society, since social institutions, such as the government, have failed to adequately address gender inequality.

In this paper, I am not asserting that women should resist sexual life nor postpone their marriages. What I want to suggest is the importance of reinterpreting these women's actions as political in order to help us overcome the political dichotomy that has oppressed women as domestics. Women's bodies and sexuality have been politicised by capitalistic-patriarchal-androcentric society and have been restricted to the domestic domain as a result of the male gaze, which subjects women to a binary between non-reproductive sex and reproductive sex. This restriction has made it difficult for women to recognise that their lived struggles are derived from a long history of gender inequity, and the choices they make in their struggles can be a form of political resistance. Viewing these women's choices as political actions is both accurate and a political action in its own right—an action that can help expand the modes of agency within the norms of Japanese femininity, and support the empowerment of women in Japan.

\footnotetext{
${ }^{9}$ For example, a 2013 annual report of the Minister of Health, Labour and Welfare shows that the percentage of extramarital children out of total birth in Japan is very low at 0.8 in 1980, and 2.1 in 2008 compared to other developed countries such as United States at 18.4 and 40.6. This suggests that many people in Japan still assume that marriage is the primary way to have children. See the Ministry of Health, Labour, and Welfare (2013), Kösei rödō bakusyo - wakamono no ishiki o bakaru [Annual Health, Labour and Welfare Report 2013], pp. 56-57.
} 


\section{REFERENCES}

Allison, A. (1994). Sexuality, Pleasure, and Nightwork: Corporate masculinity in a Tokyo hostess club. Chicago: The University of Chicago Press. https://doi.org/10.7208/chicago/9780226014883.001.0001

Araki, C. (2017). Sexless jidai no chūkōnen no sei [The sexuality of middle-aged people in the sexless era]. The Japanese Association for Sex Education, 71, 1-7.

Butler, J. (1993). Bodies That Matter: On the discursive limits of 'sex'. New York: Routledge. https://doi.org/10.11156/aibr.040303e

Salih, S. (2004). Introduction, in J. Butler \& S. Salih (eds.), The Judith Butler reader (pp. 1-17). MA: Blackwell.

Butler, J. (2009). Performativity, precarity and sexual politics. AIBR. Revista de Antropología Iberoamericana, 4(3), i-xiii. https://doi.org/10.11156/aibr.040303e

Cabinet Office, Government of Japan. (n.d.). Otto no kyōryoku [Support of husbands]. Available at: http://www8.cao.go.jp/shoushi/shoushika/data/ottonokyouryoku.html (Accessed 21 January 2018)

Cabinet Office, Government of Japan. (2009). Nippon Keizai 2009-2010 [Japanese economy 2009-2010]. Available at: http://www8.cao.go.jp/shoushi/shoushika/data/ottonokyouryoku.html (Accessed 21 January 2018)

Gotō, Y. (2015). Fūfu no 55\% wa sekkusu resu! Syōshika no mottomo shinkokuna geiin [More than 55\% of married couples are sexless! The main cause of the serious low birthrate]. All About News. Available at: https://news.allabout.co.jp/articles/d/77005 (Accessed 21 January 2018)

Hayashi, Y. (2017). Sei o kanri suru teikoku: kōsyöseido-ka no 'eisei' mondai to haisyö-undō [Controlling Sex in Empire: 'Hygiene' issues and the abortion movement under the licensed prostitution system]. Osaka: Osaka University Press.

Hosokawa, T. (2017). Füfu hansü ga sekekusu resu wariai saikō kazoku keikaku kyoukai chösa [Half of married couples are sexless. The most heighted percentage. The survey of Japan Family Planning Association]. Mainichi Shinbun. Available at https://mainichi.jp/articles/20170211/ddm/012/040/109000c (Accessed 21 January 2018)

Horie, T. (2005). Hitozuma no kenkyzu [Study about Married Women]. Chikuma Ebooks version: Available at: iBooks.

Kano, A. (2016). Japanese Feminist Debates: A century of contention on sex, love, and labor. Hawaii: University of Hawai'i Press. https://doi.org/10.21313/hawaii/9780824855802.001.0001

Kazama, T. (2003). Dōseikon no poritikkusu [The politics of same-sex marriages]. Kazoku syakaigaku kenkyu [Japanese Journal of Family Sociology], 14 (2), 32-42. https://doi.org/10.4234/jjoffamilysociology.14.32

Kitamura, K. (2015). Sei-kyōiku no atarashii kadai ni tuite kangaeru hinto o eru: 'dai-nana-kai danjyo no seikatu to ishiki ni kansuru chōsa' kekka kara [Gaining clues for thinking about the new challenges in sex education: from the result of 'the 7th survey about the lives and awareness of men and women']. The Japanese Association for Sex Education, (45), 1-7.

Kitamura, K. (2017). Kekkon shinai, sekkusu shinai wakamonotachi: 'dai-hachi-kai danjyo no seikatu to ishiki ni kansuru chōsa' kekka kara [Young people who do not marry and do not have sex: 'from the result of 'the 8th survey about the lives and awareness of men and women']. The Japanese Association for Sex Education, 72, 1-7.

Mackie, V. (1995). Imaging Liberation: feminism and socialism in early twentieth century Japan. Nepean: Women's Research Centre Press.

McCurry, J. (2017). Record numbers of couples living in sexless marriages in Japan, says report. The Guardian. Available at: https://www.theguardian.com/world/2017/feb/14/record-numbers-of-couples-living-insexless-marriages-in-japan-says-report (Accessed 21 January 2018)

Ministry of Health, Labour, and Welfare. (2013). Kösei rödō hakusyo - wakamono no ishiki o bakaru [Annual Whitepaper of the Health, Labour and Welfare Report 2013 - survey of youth's perceptions]. Available at: https://www.mhlw.go.jp/wp/hakusyo/kousei/13 (Accessed 21 January 2018)

Ministry of Health, Labour, and Welfare. (2015). Jinkō dōtai tōkei (kakuteisü) no jyōkyō [State of Vital Statistics (finalized number)]. Available at: https://www.mhlw.go.jp/toukei/saikin/hw/jinkou/kakutei14/dl/00_all.pdf (Accessed 20 August 2018)

Nemoto, K. (2008). Postponed marriage: exploring women's views of matrimony and work in Japan. Gender and Society, 22(2), 219-237. https:/ / doi.org/10.1177/0891243208315868

Rikon. [Divorce]. Saikō saiban-jyo dai-hötei [Supreme Court of Japan], minsyū 41 kan 6 gō 1423 ketsu, 41(6), 1423. Available at: http://www.courts.go.jp/app/hanrei_jp/detail2?id=55213 (Accessed 21 January 2018)

Suzuki, M. (2013). The husband's chastity: progress, equality, and difference in 1930s Japan. The University of Chicago Press Journal, 38(2), 327-352. https://doi.org/10.1086/667198

Tama, Y. (2009). 'Kindai-kazoku' to body politics [Modern Family and Body Politics], in Amano, M., Itō, K., Itō, R., Inoue, T., Ueno, C., Ehara, Y., Osawa, M., and Kanō, M. (eds.), Shinpen nibon no feminizumu [New Edition, Japanese Feminism] (pp. 304-322). Tokyo: Iwanami Syoten. 
Uchida, N. (2010). Revisiting the 'Till-3-Year-Old' Myth: Is It Really Better for Children to be Reared at Home until 3? Trend in the Sciences, 15(2), 76-86. https://doi.org/10.5363/tits.15.2_76

Ueno, C. (2003). Self-determination on sexuality? Commercialization of sex among teenage girls in Japan. InterAsia Cultural Studies, 4(2), 317-324. https:/ / doi.org/10.1080/1464937032000113060

Yamaguchi, T. (2016). Is there any truth to the portrait of a 'sexless Japan'? International Business Times. Available at: https://www.ibtimes.co.uk/there-any-truth-portrait-sexless-japan-1582495 (Accessed 19 August 2018)

Yamane, H. (2008). Ren'ai o megutte: Meiji nijyû-nendai no sexuality [About love: Sexuality in the Meiji 20 period]. Ritsumeikan Studies in Language and Culture, 19(4), 315-332.

Citation: Tsuji, R. (2018). Sexless Marriage in Japan as Women's Political Resistance. Feminist Encounters: A Journal of Critical Studies in Culture and Politics, 2(2), 22. https://doi.org/10.20897/femenc/3890

Copyright (C) 2018 by Author/s and Licensed by Lectito BV, Netherlands. This is an open access article distributed under the Creative Commons Attribution License which permits unrestricted use, distribution, and reproduction in any medium, provided the original work is properly cited. 